\title{
The Impact of the Monetary Policy on the Economic Growth and the Development of the Republic of Macedonia
}

\author{
Neritan Turkeshi \\ (PhD, FON University, Skopje, R.Macedonia) \\ Shkodrane Dardhishta (MBA)
}

Doi:10.5901/mjss.2013.v4n11p770

\begin{abstract}
Upon the monetary independence of the country from the previous joined state, it began with the creation (construction) of new own monetary system and implement its own authentic monetary policy. Besides the implementation of the projected primary monetary objectives (maintenance of price stability and stability of the purchasing power of money, i.e. internal and external value of the denar), the monetary authority cares for the realization of other basic goals of macroeconomic policy, such as: providing a higher rate of economic growth, increased foreign trade, especially exports, increasing the employment and improving the balance of payments positions. The realization of these macroeconomic objectives is possible if, with the measures of macroeconomic policy, and in this framework, monetary policy measures, are created the: favorable conditions for management(expansion of production capabilities, better utilization of available resources, adequate location and prompt reallocation of resources), improving economic relations and trade cooperation, aimed at increasing foreign trade, especially exports and improve the current account positions, and thus the position of the balance of payments.
\end{abstract}

\section{Introduction}

If we consider the factor that, the realization of the bigger part of the previously mentioned objectives requires comprehensive engaging of all players (business sector, authorities and the government institutions) responsible for the realization of economic objectives (economic, development, exporting), higher level of coordination and cooperation between business sector, authorities and institutions, engaging the larger volume of funds, in function at increasing the productive capacity of the domestic economy, and the need of the relatively long period of time, so the effects of undertaken measures will reflect the value of the macroeconomic indicators. If we consider the fact that, economic reforms implemented in the previous period, especially so-called structural reforms, are seen as insufficient and delayed success. Then, lack of funds for investments, in function of increasing commodities of physical and human capital, in the whole period after economic independence, led to further deepening of the so-called distance in the technical and technological development of the domestic economy.

In such circumstances, the major part of the task, to secure better business conditions, while in a function of reforms of the domestic economy, fell on the monetary and fiscal policy. If we consider the fact that, the effects of measures and instruments of monetary and fiscal policy cannot completely cover the failures and disadvantages in the implementation of other policies (production, development and export policy, the primary distribution of income tax and other), then the implementation of sustainable and efficient monetary and fiscal policy, according to the needs and demands of the domestic economy, may partially successfully and in the short term, to resolve disadvantages, weaknesses and obvious limitations of the domestic economy. Of course, in the economic theory there are other views and opinions, often conflicting, in view of the role and importance of monetary policy on economic growth and development. Thus, according to them, restrictive monetary policy is the main limiting factor to reduce the production activity in the country. In addition to the previously mentioned attitude, the author lists the following arguments:

- Through quantitative restrictions on credit growth, banks, respectively monetary institutions have limited the access of the enterprises to the working capital, which was necessarily required to finance current production;

- Restrictive monetary policy is the reason, respectively one of reasons for the deterioration of liquidity of the economy;

- Restrictive monetary policy led to increased interest rates;

- Restrictive monetary policy led to the establishment of intercurrence value of denar, i.e. exchange rate of denar, on a higher level in terms of real value of money, which had a negative impact on the competitive ability of domestic exporters. 
Although the foregoing arguments stand, we still believe that the monetary policy together with fiscal policy had a significant impact on economic trends. The measures of monetary and fiscal policy for a relatively short time, it was managed to achieve a higher level of price stability, stability of the purchasing power of money and stability of the exchange rate of national currency, which is essential precondition for creating a stable macroeconomic environment. The failure, i.e. partial success in implementing the reforms, particularly the so-called structural reforms, the failure in improving the economy structure, insufficient allowance for investment, unfavorable structure in the primary distribution of earned income, are the reasons for the unfavorable development of real economic trends. In such a situation, measures of monetary and fiscal policy can partly influence the actual economic flows, but not completely changing direction (development tendency) to actual economic flows. The character of monetary policy (restrictive, expansive or neutral) basically depends primarily on the state of national economy and the objectives of macroeconomic policy.

\section{The impact of monetary policy on the economic growth}

Period after economic and monetary independence from the previous joint state union is characterized by worsened economic situation (negative rates of economic growth, high unemployment and the state of economic instability) and the unfavorable tendency of development of economic flows. The main reasons for the deteriorating condition of the domestic economy, as previously mentioned are: the failure, that partial success in implementing economic reforms, especially the so-called structural reforms, then the inability of the domestic economy to face foreign competition, lack of funds for investment and failure in attracting foreign investments (in function at changing the existing economic structure and function of increasing freight of physical and human capital) prolonging transformation of capital (process privatization and restitution). Also, a great impact on the situation and unfavorable development of economic trends in the past have the so-called external shocks on the domestic economy (military actions in the premises of former Yugoslavia, Greek blockade to us, blockade of the UN towards Serbia, military actions in the country during 2001, etc.).

The literature in the field of monetary theory and policy can be met different views and attitudes regarding the impact of various factors, and in this framework, the impact of monetary policy measures. In the early stage of transition in all former socialist countries, there was a decline in economic activity, and in extreme cases, the real decline in GDP in those countries are reduced to only $50.0 \%$ of the level reached before the transition(petrevski 2005). The main reasons for the entry of these economies in the so-called transformation recession period are: the autonomous movements in demand as a result of liberalization, the collapse of the former joined markets, and breaches occurred in the supply of goods of domestic origin, the failure of previous generation capacities and insufficient investment to build new ones. Also, the opinion of a larger number of domestic economic theorists is that the stabilization policy is one of the reasons for the decline in economic activity in the country. Restrictive approach to the conduct of monetary policy leads to: decrease the amount of funds on behalf of credit loans, deterioration of liquidity, growth of the interest rates and condition of an overestimated exchange rate of national currency, causing growth of cost of production, and thus reduction of the competitive ability of the domestic economy, in the internal and external markets (Prevalla 2005). According to the State Statistical Bureau, in the period 1992-1995, when implemented stabilization program, the national economy has achieved negative growth rates, although the rates of monetary growth had been very high.

Table 1. Rates of growth of GDP, monetary growthand the rates of inflation in BO $\%$

\begin{tabular}{|l|l|l|l|l|l|l|l|l|l|l|}
\hline Years & 1992 & 1993 & 1994 & 1995 & 1996 & 1997 & 1998 & 1999 & 2000 & 2001 \\
\hline $\begin{array}{l}\text { Growth of } \\
\text { GDP }\end{array}$ & $-6,6$ & $-7,5$ & $-1,8$ & $-1,1$ & 1,2 & 1,3 & 3,4 & 4,3 & 4,5 & $-4,5$ \\
\hline $\begin{array}{l}\text { Monetary } \\
\text { growth }\end{array}$ & 704,5 & 236,6 & 87,9 & 19,2 & 0,9 & 13,2 & 13,3 & 29,4 & 20,9 & 57,2 \\
\hline Inflation & 1511,3 & 362,0 & 128,3 & 15,7 & 2,3 & 2,6 & $-0,1$ & $-0,7$ & 5,8 & 5,5 \\
\hline
\end{tabular}

\section{Extension:}

\begin{tabular}{|l|l|l|l|l|l|l|l|l|}
\hline 2002 & 2003 & 2004 & 2005 & 2006 & 2007 & 2008 & 2009 & 2010 \\
\hline 0,9 & 2,8 & 4,6 & 4,4 & 5,0 & 6,1 & 5,0 & $-0,9$ & 1,8 \\
\hline$-16,7$ & 14,8 & 14,2 & 16,9 & 21,2 & 29,2 & 11,1 & 3,9 & 10,3 \\
\hline 1,8 & 1,2 & $-0,4$ & 0,5 & 3,2 & 2,3 & 8,3 & $-0,8$ & 1,6 \\
\hline
\end{tabular}

Source: State Statistical Bureau, Annual reports by year 
From the indicators presented in Table 1 certain conclusions and findings can be drawn, including:

- Despite the fact that the in the period of 1992-1995 it was led an expansionary monetary policy, with a tendency of increased restrictiveness of the year, according to the foundations laid by the stabilization program, the rates of economic growth are negative (from $-6.6 \%$ in $1992-1.2 \%$ in 1995), suggesting that, there is no correlation, or causal relationship between economic growth and the growth of monetary factors. This means that, the reason for recession movements are other factors and constraints;

- The period 1996-2010 was characterized by positive rates of economic growth (except in 2001 and 2009), although lower than the projected values. Positive economic growth rates are achieved in the years when monetary growth was positive but also in the years when the monetary growth was negative (2002). Also, the rates of economic growth are higher in years when monetary growth was high, but also in the years when the rate of monetary growth was lower, indicating that, there is no causal link between monetary growth and economic growth.

From the foregoing it can be concluded that the effects of application of the measures of monetary policy are positive, especially in creating a stable macroeconomic environment (price stability, stability in the purchasing power of money in the domestic market and the stability of the exchange rate). However, measures of the monetary policy are shown as insufficiently effective in stimulating economic growth and boost the employment. This situation in the medium and long term is unsustainable and is a matter of time before a breach of the established state of macroeconomic stability, because the current internal balance is maintained by increased imports. Increased imports cause growth of the trade deficit, which in turn causes a greater outflow of funds from the current account of balance of payments. So far it was mostly covered by foreign borrowing, but the question is until when, and in the same time the maintenance the external balance not to be questioned.

\section{The impact of the monetary policy on foreign trade exchange}

Measures of the macroeconomic policy, and in this framework the monetary policy measures, have an impact on the development of foreign trade. Every economy seeks to increase the volume of foreign trade, in order to better supply the domestic market with necessary goods and services on the one hand, and to increase exports of goods and services from domestic production in the foreign market. The basic question that imposes during the performance of foreign trade is the way of calculation and execution of payments, when each national economy has its own national currency and its own policies determining the exchange rate of national currency. The answer to this question, or dilemma, is the following: national monetary units are a tool of payment in the internal market, while in the foreign trade, as a tool of payment are used the currencies of economically developed countries, such as: the U.S. dollar, euro, Japanese yen, British pound, Swiss franc, Russian ruble and others.

Of particular importance in the pursuit of the foreign trade is receiving adequate equivalent in goods or money, in order to preserve the material substance of the domestic economy. This is achieved by determining the parity value of the national currency unit or its intercurrence value. Monetary authority shall establish and monitor the changes of the intercurrence value, i.e. the exchange rate of national currency, the purpose of realization of the basic macroeconomic objectives, and in that context and function of realization the purposes of foreign trade policy of the country. ${ }^{1}$ Depending on the state of the national economy (level of economic development, stage of economic cycle, the level of development of relations in foreign trade) and the system of targets that are expected to be realized, the exchange rate of national currency can be set at realistic grounds, be undervalued or overvalued. In market conditions, the change in exchange rates of national currencies depends on their supply and demand of foreign exchange market. When the supply and demand of foreign currencies in the foreign exchange market are not balanced relation, it comes to a deviation in the direction of increase or decrease of the real exchange rate in relation to the official exchange rate. The change in the exchange rate leads to a change of parity, i.e. the ratio of the value (intercurrence) of separate currencies. In order to sustain the stability of the established exchange rate of the national currency, the interventions of monetary authorities in the foreign exchange market are often, by using a number of monetary instruments at its disposal.

In principle, each national economy seeks to determine the exchange rate of national currency on the real basis, aware of the benefits of this way of determining the parity of the national economy. Under the real exchange rate it implies such a relationship in foreign exchange, which allows, purchase of the same amount of goods and services in the internal market, with one or 100 units of national currency, as you can buy the equivalent amount of money stated in

\footnotetext{
${ }^{1}$ Dr. Aleksandar Zhivkovic and Dr. Gradimir Kozhetinac, Monetary Economy, Economic faculty - Belgrade, 2005, page 550.
} 
foreign currency. For example, the exchange rate is considered a real set, if for 61 denars you can buy a certain quantity of goods in the domestic market, as you can buy for one euro on the foreign market.

\section{The impact of monetary policy on the internal and external balance}

Monetary policy has a major impact on the maintenance, or reestablishment of the internal and external balance. No economy is not completely immune from the state of imbalance, but the difference between them is that both (the developed economies) often succeed in a short time to re-establish a state of equilibrium, compared to other economies (the underdeveloped and developing countries). ${ }^{2}$ The state of internal imbalance often causes distortion and external balance and the opposite. As the most frequent reasons (factors) that lead to a state of imbalance are mentioned:

- $\quad$ the impact of factors of material nature;

- $\quad$ the impact of factors of monetary nature.

If within a national economy there is an insufficient supply of goods and services of domestic origin, then it is forced to reduce the amount (value) of domestic demand or to increase the import. In conditions of a liberalized market, that lack of sufficient supply of goods and services of domestic origin shall be filled by increased imports. If a national economy is set to limit the demand on the level of domestic offer, it is possible that it will come to a disruption of internal balance, as a consequence of imbalance between commodity and purchase funds.

\section{The role of the state in this process}

The role of the state in implementation of the restructuring and rehabilitation of the banks is extremely important. Such a significant state role in this process can be viewed from several aspects as follows:

a. State through its budget provides most of the funds in order to implement the process of restructuring and rehabilitation of the banks. Given the fact that, for successful accomplishment of the process of restructuring and rehabilitation of the banks, according to some evaluations funds in the amount of 5-6\% of GDP of the country are needed. The funds required for the project should be used for the:

- Payment of the interest to the foreign currency deposits of these banks;

- Payment of the interest on bonds issued by the Agency for rehabilitation of the banks, in exchange for writing off bad and doubtful claims on the base of credit loans to banks, amounting to $50 \%$ of their amount;

- Payment of the interest on the liabilities of the banks on the basis of used foreign loans and guarantees given;

- Regular servicing of foreign currency deposits of citizens, whose amount, according to some estimation, moves at about $3 \%$ of the GDP of the country.

b. Providing additional resources of funds for implementation of the process of rehabilitation of the banks. Given the limited capabilities of the State Budget to fully fund this project, it was assessed as a requirement to be used additional sources of funds, primarily from international financial institutions, or request for an approval from them for reprogramming the debts of banks and enterprises for a period of time.

Still, the biggest part of the burden from implementation of the process of restructuring and rehabilitation of the banks felt on the budget of the country, the methodology of implementation of this process was conceived in that way, that the entire obligations which come out from this project should be divided into: 1. Obligations of the economy and the banks which were faced with the so-called bad loan placements to be solved with the help of the state, and 2 . The obligations in behalf foreign currency deposits of the population to be solved in the way that more solutions and alternatives are offered: introduction of transferable certificates based on the voluntarily conversion of the foreign currency deposits. These certificates could be used to buy real goods, to buy securities and the same could be bought and sell on the secondary market of the capital. The second opportunity which is given to the deponents of foreign currency deposits is buying of stocks of the bank which is client of their deposits. Third opportunity is transfer of the foreign currency deposits of the citizens into denar deposits. Fourth opportunity is the right with the foreign currency deposits to buy apartments, business offices and other type of property which is in social ownership and the last opportunity is freezing of the foreign currency deposits on certain time period ${ }^{3}$. The choice which alternative will be taken is a decision of the foreign currency deponents in the banks.

\footnotetext{
2 N.Gregory Mankiw, Mrk P. Taylor, Economics, translated SP Print-Belgrade, 2008, page 594.

${ }^{3}$ M. Chirovic: "Banking", Bridge Company, Belgrade, 2001, page 309.
} 


\section{The role of the NBRM}

The role of the NBRM in the process of restructuring and rehabilitation of the banks is specific, given the fact that as the highest monetary authority in the country, conducts the legally determined functions and supervisions. The impact of the NBRM on the process of rehabilitation of the banks although indirectly, is very significant. That impact of the NBRM comes into expression especially:

- through the instruments of the monetary regulation, the NBRM influences on the level of liquidity in the economy, in the way that in conditions of bigger liquidity of the banking sector she intervenes, and with that it reduces the pressure of the borrowers for new loans, but in the same time the mechanism of monetary regulation reduces also the loan potential of the banks, and that narrows the opportunity for new loan placements. In that way is prevented the possibility banks to create new, so-called bad placements of funds;

- through the mechanism of the enhanced control in the working of the banks, in regard to the respect of the legal regulations and other bylaws, as well as the order and decisions of the monetary authority in regard to the amount of credit multiplication, the criteria of approving new placements, the amount of the banking guarantees etc.;

- through the enhanced control while issuing agreements for founding new banks. Namely, when issuing a license to found a bank, the criteria should be strengthened, with the aim new banks to be able to found only those investors who secured appropriate amount of founding capital, business policy and professional personnel, who will be capable of carrying the problem of banking operations.

In no case, the NBRM shouldn't be directly involved in the process of rehabilitation of the banks, nor in the role of financing institution of the activities of the institution in charge of implementing the project, nor in the role of direct bearer of implementation of the project for rehabilitation of the banks.

\section{Conclusion}

Regarding the impact of the monetary policy on the development of the banking sector in Republic of Macedonia in the previous period (2005-2010) the most important measures which led to the dynamic growth of this sector can be listed, such are:

- Determination of low census, i.e. founder capital for the establishment of new banking institutions. The minimum amount for the establishment of a bank was set at 3 million DEM and 1 million DEM for the establishment of a branch of a foreign bank in the country, in MKD;

- Reorganization and consolidation of the banking sector. The process of consolidation of the banking business, encompassed activities within the domain of the reorganization of the existing banks, establishment of new banking entities, and their restructuring in accordance with the Law on banks and savings of 1991;

- Measures with which was predicted rehabilitation of the banking institutions. With the process of rehabilitation of the banks was envisaged: cleaning banks' balance sheets of so-called dubious in the previous operations of the banks, restructuring and recapitalization of the banks.

The process of rehabilitation of the banks started in 1990/91, through the so-called process of linear rehabilitation of the banks, and then followed a process of further rehabilitation of each bank separately;

- Liberalization of the domestic financial market, which give the possibility for establishment of banks and other banking institutions by foreign entities, mainly banks and other financial institutions. As result of such an approach, the value of foreign capital in the banking sector in Republic of Macedonia, of 31.12. In 2001 exceeds 110 million U.S. dollars, which is seen as a successful approach in attracting foreign capital, as in the formation of new banking institutions (new banks), as well as investments of foreign banks in the existing banking institutions. This led not only to the increase of the banking capital, but also to a change of the ownership structure of banking sector in Republic of Macedonia. The participation of foreign capital in total banking sector in the period $2005-2010$ in the country increased from $49.1 \%$ in 2005 to $85.5 \%$ in 2010. In the same period the share of the domestic private capital in the total banking sector decreased from $46.4 \%$ in 2005 to $9.2 \%$ in 2010. The participation of state capital in total banking sector varies from $4.5 \%$ in 2005 to $5.3 \%$ in 2010. The increase of the participation of the foreign capital in the total banking sector in the country mainly was conducted through the purchase of shares of some domestic banks by foreign banks (In April 2010, 93.8\% of the shares of Stater Banka AD Kumanovo were purchased by the Central Cooperative Bank AD Sofia, then through the recapitalization of some banks (Alpha Bank AD Skopje, Ohrid Bank AD Skopje and Ziraat Bank AD Skopje) and by the conversion of so-called priority shares into ordinary shares; 
- Measures of the monetary authority in regard to the policy of lending to the commercial banking, then measures in the domain of policies for determining the discount rate, the amount of mandatory reserves, and the measures which give the opportunity to expand the scope of activities in the domain of the deposit and credit activity of bank institutions. As a result of the growth of the activities of the banking sector in the country, especially the deposit activity increasing the socalled core deposits in the banking sector. Although the growth of the deposit activity in the period 2005-2010 was several times higher (index 230.1), the credit activity of the banking sector during the same period was below the level of secured assets (credit potential of the banking sector). The dynamics of growth of credit activity in the banking sector in the investigated period (index 204.7) is lower than the dynamic growth of the deposit activity, leading to the increased liquidity in the banking sector, on one hand, and the declining level of cost-effectiveness and profitability in the operations of the banking sector, on the other hand. Consequently, some banks, especially the so-called large banks, they direct part of their credit potential the last few years towards purchase of securities (bonds and treasury bills);

- As a result of the expanded activities of the banking sector and the successful implementation of the determined policy of development, was ensured a higher stability in the operations, and an increase of the level of trust and reliability in the operations of our banking sector. Achieved success primarily is due to the increase of own funds (capital of banks) and thus the credit potential in most of our banking institutions. The increase of the own funds of most part of our banks is primarily a result of the rising census for establishment of new banks, then undistributed profits from previous years, particularly as a result of several emissions of new share by the banks, which was in function of recapitalization of banks, leading to a quantitative increase of the capital of the banking sector, and to a qualitatively improvement of the structure of the funds available to the banking sector in the country.

\section{References}

Goran Petrevski, Monetary policy, Association for socio-economic development, Skopje, 2005

Shaban Prevalla, Banking, Skopje, 2005.

N.Gregory Mankiw, Mrk P. Taylor, Economics, translated SP Print-Belgrade, 2008, page 594.

Aleksandar Zhivkovic and Dr. Gradimir Kozhetinac, Monetary Economy, Economic faculty - Belgrade, 2005, page 550.

M. Chirovic: "Banking", Bridge Company, Belgrade, 2001, page 309. 